\title{
Penerapan Metode Problem Based Learning untuk Meningkatkan Hasil Belajar Materi Barisan dan Deret Bilangan Pada Siswa Kelas IX E SMPN 1 Kalidawir
}

\author{
Paryitno $^{1}$ \\ ${ }^{1}$ SMPN 1 Kalidawir, Tulungagung \\ Email: ${ }^{1}$ prayitno@gmail.com
}

\begin{tabular}{l}
\hline Tersedia Online di \\
\hline http://www.jurnal.unublitar.ac.id/ \\
index.php/briliant \\
\hline \\
\hline Sejarah Artikel \\
Diterima pada 11 Februari 2018 \\
Disetuji pada 11 Februari 2018 \\
Dipublikasikan pada 13 Februari \\
2018 Hal. 61-69
\end{tabular}

\section{Kata Kunci:}

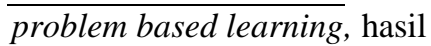
belajar, barisan dan deret

bilangan,

\section{DOI:}

http://dx.doi.org/10.28926/briliant .v3i1.140

\begin{abstract}
Abstrak: Berdasarkan hasil observasi yang dilakukan di Kelas IX E pada waktu pembelajaran Matematika diperoleh hasil bahwa Hasil belajar siswa kurang memuaskan, yaitu dari 32 siswa hanya 13 siswa yang nilainya dapat mencapai $\mathrm{KKM}$ atau $\geq 70$, sedangkan 19 siswa lainnya masih belum dapat mencapai $\mathrm{KKM}$ atau $\leq 69$. Hal ini disebabkan karena guru kurang memberikan penekanan materi yang jelas tentang Barisan dan Deret Bilangan tersebut. Untuk itu agar dapat meningkatkan Hasil belajar siswa dalam menyelesaikan soal tentang Barisan dan Deret Bilangan serta untuk tercapainya tujuan pembelajaran perlu diadakan perbaikan pembelajaran dengan menerapkan Metode Problem Based Learning. Penerapan pembelajaran Barisan dan Deret Bilangan melalui Metode Problem Based Learning dapat meningkatkan Hasil belajar siswa Kelas IX E SMP Negeri 1 Kalidawir Tulungagung dan dapat mempermudah siswa dalam menyelesaikan persoalan Barisan dan Deret Bilangan.
\end{abstract}

Pelaksanaan pendidikan dan segala kegiatan pendidikan diarahkan untuk mencapai tujuan pendidikan nasional. Dalam Undang-undang No.20 Tahun 2003 disebutkan bahwa, Pendidikan nasional berfungsi untuk mengembangkan kemampuan dan membentuk watak serta peradaban bangsa yang bermartabat dalam rangka mencerdaskan kehidupan bangsa, bertujuan untuk mengembangkan potensi peserta didik agar menjadi manusia yang beriman dan bertaqwa kepada Tuhan Yang Maha Esa, berakhlak mulia, sehat, berilmu, cakap, kreatif, mandiri dan menjadi warga negara yang demokratis dan bertanggung jawab.

Untuk mencapai tujuan pendidikan nasional maka disusunlah kurikulum atau disebut juga isi pendidikan yang merupakan komponen penting dalam dan atau bagian integral dari sistem pendidikan sekaligus pedoman pelaksanaan pengajaran pada semua jenis dan tingkat sekolah. Perubahan paradigma pengembangan kurikulumdi Indonesia diawali dengan lahirnya peraturan pemerintah No.19 Tahun 2005 tentang Standar Nasional Pendidikan dan kemudian diikuti oleh Permendiknas No.23 Tahun 2006 tentang Standar Kompetensi Lulusan untuk Satuan Pendidikan Dasar dan Menengah dan Permendiknas No.22 Tahun 2007 tentang standar isi untuk Satuan Pendidikan Dasar dan Menengah. 
Bruner (dalam Hudoyo, 1988:56) mengatakan tentang belajar Matematika sebagai berikut: Belajar Matematika adalah tentang konsep-konsep dan struktur-struktur Matematika yang terdapat dalam materi-materi yang dipelajari serta menjalankan hubungan antara konsep-konsep dan struktur-struktur itu. Lain dari itu peserta didik lebih mudah mengingat Matematika itu, bila yang dipelajari merupakan pola yang terstruktur.

Salah satu model pembelajaran yang dapat mengakomodasi kepentingan untuk mengkolaborasikan pengembangan diri di dalam proses pembelajaran adalah model pembelajaran kooperatif. Ide penting dalam pembelajaran kooperatif adalah membelajarkan kepada siswa keterampilan bekerjasama dan berkolaborasi. Keterampilan ini sangat penting bagi siswa, karena pada dunia kerja sebagian besar dilakukan secara berkelompok.

Dalam proses pembelajaran di kelas sering timbul masalah yang pada umumnya dialami oleh siswa. Masalah yang dihadapi siswa bersifat unik berbeda satu sama lain. Misalnya masalah dan kesulitan ataupun rendahnya hasil belajar yang dialami siswa pada mata pelajaran Matematika bisa terjadi karena berbagai faktor diantaranya. (1) Keterbatasan kemampuan, keadaan, minat dan motivasi diri siswa itu sendiri. (2) Situasi belajar di sekolah atau kelas dan kurangnya sarana dan prasarana. (3) Materi pelajaran yang kurang relevan dengan kebutuhan siswa. (4) Metode mengajar yang kurang bisa dipahami siswa bahkan kurangnya alat peraga dan alat bantu mengajar.

Apalagi mata pelajaran Matematika menuntut kemampuan Guru untuk bisa membuat siswa mengerti dan memahami tentang materi yang diajarkan dengan tidak hanya membaca buku dan teori saja melainkan harus disertai alat peraga, contoh, praktek, latihan soal, seperti soal bercerita dan sebagainya, agar siswa memiliki pengetahuan, keterampilan dan bahkan sikap ilmiah yang berujung pada pemerolehan prestasi belajar yang maksimal.

Berdasarkan hasil pengamatan dalam proses belajar mengajar dikelas, keadaan sekolah, dan melalui peninjauan bidang akademik dan non akademik, diperoleh hasil bahwa keadaan SMP Negeri 1 Kalidawir Tulungagung khususnya siswa kelas IX E tahun ajaran 2016/2017 dalam pelajaran Matematika belum menunjukkan hasil belajar sesuai dengan KKM yang ditetapkan terutama pada pengerjaan Barisan dan Deret Bilangan. Padahal, ditinjau dari keadaan fisik sekolah, yaitu ruang kelas IX E sudah baik dan sesuai sebagai tempat berlangsungnya proses belajar mengajar. Pengamatan pada proses pembelajaran oleh peneliti dapat disimpulkan bahwa pelaksanaan proses belajar mengajar lah yang belum membuat siswa aktif belajar, sehingga kemampuan siswa belum tergali dengan maksimal.

Pada ulangan harian Matematika dengan Barisan dan Deret Bilangan, di dapat rata-rata nilai sebesar 63,6 dari 32 siswa, padahal Kriteria Ketuntasan Minimalnya (KKM) telah ditentukan nilai sebesar 70. Dan hanya 13 siswa yang mendapat nilai di atas 70 . Hal ini berarti, hanya 40,6\% dari siswa yang telah mencapai ketuntasan belajar, dan yang lainnya memiliki prestasi belajar yang rendah.

Berdasarkan hal tersebut, peneliti meminta bantuan kepada teman sejawat untuk meneliti kekurangan dari pembelajaran yang telah dilaksanakan. Dari hasil diskusi dengan teman sejawat ditemukan masalah-masalah dalam proses pembelajaran Matematika yang menyebabkan menurunkan hasil belajar 
adalah sebagai berikut: (1) Materi kurang dapat dikuasi siswa secara optimal. (2) Siswa belum dapat menyelesaikan soal Barisan dan Deret Bilangan. (3) Melihat hasil ulangan harian siswa diatas, bisa dilihat jika penggunaan metode pembelajaran dalam pembelajaran Matematika pada siswa kelas IX E belum sesuai dan membuat siswa terlihat tidak antusias untuk belajar. (4) Pembelajaran dengan metode konvensional yaitu dengan menjelaskan materi dan siswa hanya melakukan perintah mengerjakan soal tanpa penanaman konsep pembelajaran yang kuat ternyata tidak efektif dalam proses peningkatan prestasi belajar siswa.

Setelah melihat hasil analisa di atas dan tukar pendapat dengan teman sejawat, maka untuk memperoleh hasil belajar yang optimal, tidak hanya memerlukan suatu latihan yang terus menerus, tetapi terlebih dahulu siswa harus mengetahui inti dari materi yang dipelajarinya. Berdasarkan konsep yang mereka temukan sendiri di dalam proses pembelajaran, tentu siswa akan lebih bersemangat, dan aktif belajar serta berusaha mencari penyelesaian masalah yang diberikan oleh Gurunya dengan menggunakan kemampuannya sendiri.

Adanya semangat atau motivasi siswa dalam belajar dan konsep yang tertanam dengan baik, diharapkan siswa mampu menyelesaikan setiap tugas yang diberikan dengan prosedur yang benar, sehingga hasil belajar yang diperoleh menjadi lebih baik dari semula serta terjadi peningkatan prestasi belajar siswa.

Oleh karena itu, demi memperbaiki berbagai masalah yang ada, peneliti memerlukan suatu solusi untuk mengatasi hambatan-hambatan yang terjadi. Akhirnya diputuskan dengan menggunakan Metode Problem Based Learning dalam pembelajaran Matematika ini.

Metode Problems Based Learning adalah siswa akan bekerja secara kooperatif dalam kumpulan untuk menyelesaikan masalah sebenarnya dan yang paling penting membina kemahiran untuk menjadi siswa yang belajar secara sendiri. Metode Problems Based Learning merupakan kemampuan berpikir siswa secara kritis dan kontinu berkaitan dengan ide yang dihasilkan serta yang akan dilakukan. Dalam melaksanakan proses pembelajaran Problem Based Learning. Dengan menggunakan pendekatan Problem Based Learning ini, siswa akan bekerja secara kooperatif dalam kumpulan untuk menyelesaikan masalah sebenarnya dan yang paling penting membina kemahiran untuk menjadi siswa yang belajar secara sendiri.

\section{METODE}

Penelitian tindakan sekolah ini dilaksanakan di ruang kelas IX E SMP Negeri 1 Kalidawir Tulungagung. Pada semester 2, pada tanggal 5 April 2017 sampai dengan 12 April 2017. Dalam penelitian ini subjek yang digunakan adalah seluruh siswa kelas IX E SMP Negeri 1 Kalidawir Tulungagung tahun pelajaran 2016/2017 sebanyak 32 siswa yang terdiri dari 13 siswa putra dan 19 siswa putri.

Berdasarkan variable yang diteliti dan tujuan yang hendak dicapai, mata metode penelitian yang digunakan adalah dengan teknik korelasi. Dengan berbagai metode yang digunakan peneliti, peneliti berupaya untuk meningkatkan hasil belajar Matematika terutama pengerjaan Barisan dan Deret Bilangan siswa kelas IX E SMP Negeri 1 Kalidawir Tulungagung dengan menggunakan Metode Problems Based Learning.

Berdasarkan hasil pengidentifikasian dan penetapan masalah, peneliti kemudian mengajukan suatu solusi yang berupa penerapan Metode Problems 
Based Learning yang dapat dimanfaatkan Guru untuk digunakan sebagai metode pengajaran dalam pembelajaran Matematika kelas IX E SMP Negeri 1 Kalidawir Tulungagung.

Penelitian ini dilakukan dengan dua siklus, dimana masing-masing siklus dikenai perlakuan yang sejenis dengan bobot yang beda. Dibuat dua siklus dimaksudkan untuk memperbaiki system pengajaran yang dilaksanakan.

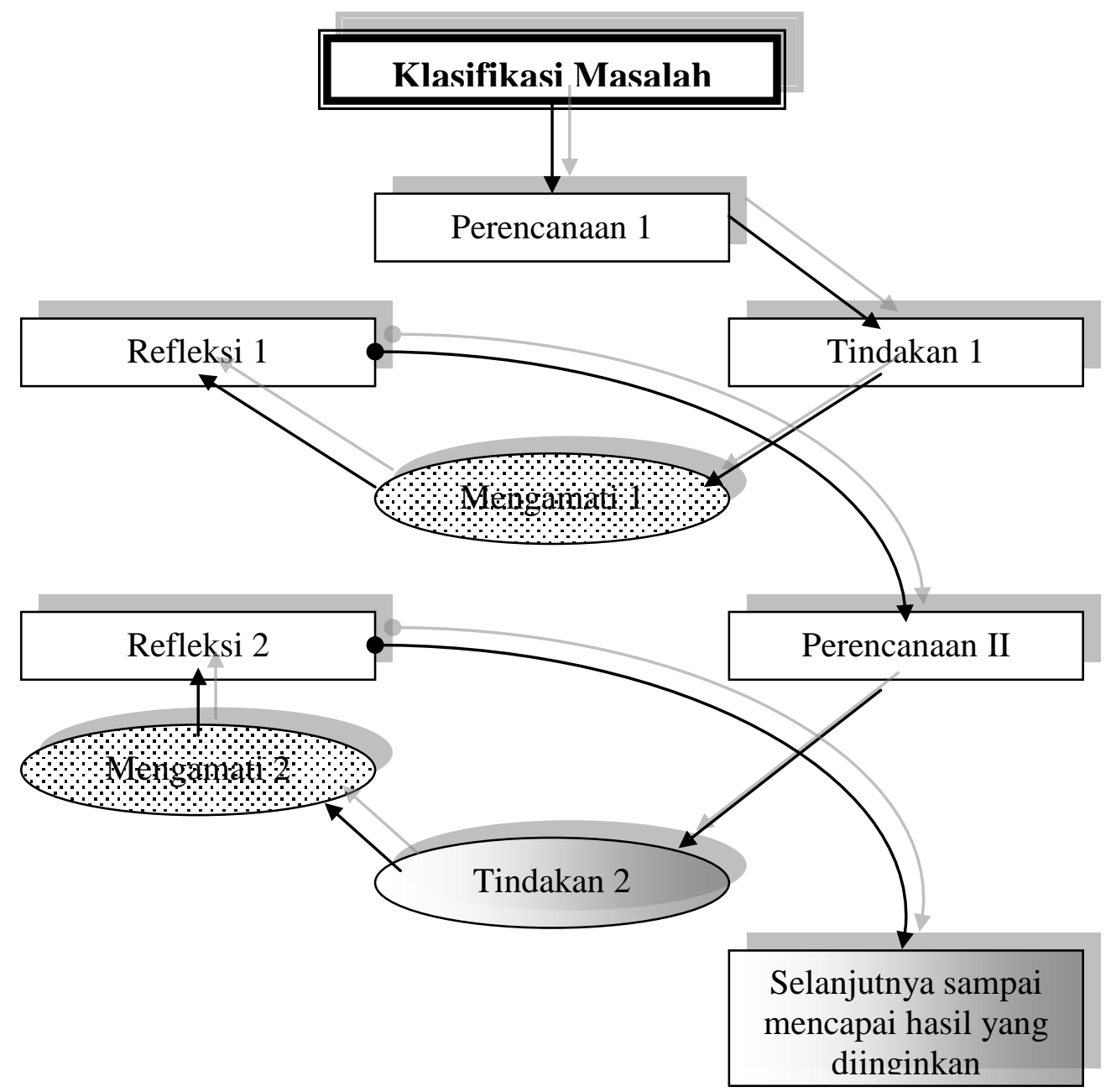

Gambar 1 Langkah-Langkah PTK dengan 2 Siklus

Instrumen yang dikembangkan oleh Guru sebagai peneliti disesuaikan berdasarkan kebutuhan data penelitian itu sendiri. Guru atau peneliti mengidentifikasi dan mempersiapkan berbagai ragam instrument yang diperlukan dalam penelitian tindakan kelas ini. Guru ataupun peneliti mempersiapkan instrument penelitian dengan tepat, tentunya supaya data yang terkumpul dapat lebih bermakna dan bermanfaat bagi kegiatan penelitian.

Adapaun ragam instrument penelitian tindakan kelas yang telah dipersiapkan yaitu, Rencana Pelaksaaan Pembelajaran sebagai instrument rencana pelaksanaan tindakan. Lembar observasi Guru sebagai instrument utama pengumpul data proses dan lembar observasi siswa, wawancara, angket dan catatan lapangan sebagai instrument pendukung pengumpul data proses. Selain itu 
juga terdapat instrument pengumpul data hasil, yang dapat dikumpulkan dari hasil belajar berdasarkan soal-soal yang diberikan, serta ketrampilan siswa berdasarkan rubrik yang ada.

Teknik analisis yang digunakan yaitu deskriptif persentase. Data hasil penelitian yang dianalisis meliputi rata-rata kelas, ketuntasan belajar individu dan ketuntasan belajar secara klasikal. Selanjutnya hasil analisis data diperoleh baik secara kualitatif (dengan kata-kata) dan kuantitatif (dengan grafik). Hasil ini diinterprestasikan dan disimpulkan untuk menjawab permasalahan yang ada. Analisis data dari sumber-sumber informasi hasil penelitian di dapat dari: 1) Analisis dara observasi, 2) analisis data wawancara, dan 3) analisis data tes.

\section{HASIL}

\section{Siklus I}

Dalam pelaksanaan pembelajaran, Guru masih menghadapi berbagai kendala, antara lain: 1) Masih ada kelompok yang bingung dalam mengikuti langkah-langkah yang tertera dalam lembar kegiatan. 2) Masih ada beberapa siswa yang belum aktif dalam pelaksanaan diskusi. 3) Ketika pelaksanaan diskusi, ada beberapa siswa yang tidak aktif menyampaikan pendapatnya. 4) Dalam menyimpulkan hasil diskusi, terdapat 2 (dua) kelompok yang malu untuk presentasi, dan hanya terdapat 3 (tiga) siswa yang mengajukan pertanyaan.

Adapun prosentase hasil observasi dalam pelaksanaan diskusi pada siklus I dapat dilihat dari tabel 3 bawah ini. Perhitungan prosentase keberhasilan siklus I di bawah ini diskusikan juga dengan teman sejawat.

Tabel 1 Prosentase Hasil Observasi Siklus I

\begin{tabular}{|l|l|l|}
\hline No & Kegiatan Siswa & Prosentase \\
\hline 1 & Kelengkapan menyiapkan alat dan bahan diskusi & $45 \%$ \\
\hline 2 & Keruntutan langkah-langkah dalam pelaksanaan kegiatan diskusi & $45 \%$ \\
\hline 3 & Keaktifan siswa selama melaksanakan kegiatan diskusi & $60 \%$ \\
\hline 4 & Keaktifan siswa dalam mengutarakan pendapat saat berdiskusi & $50 \%$ \\
\hline 5 & Kesimpulan akhir sesuai diskusi & $50 \%$ \\
\hline
\end{tabular}

Hasil post test pada siklus pertama dapat menjadi perhitungan persentase peningkatan prestasi hasil belajar siswa. Dengan acuan penilaian tetap berdasarkan nilai KKM yang telah ditetapkan yaitu paling sedikit siswa memperoleh nilai 70. Adapun rekapitulasi hasil test siklus I adalah sebagai berikut:

Tabel 2 Hasil Post Test Siklus Pertama

\begin{tabular}{|l|l|l|}
\hline No & Deskripsi & Nilai \\
\hline 1 & Jumlah Nilai & 2335 \\
\hline 2 & Rata-rata Hasil Post Test & 73,0 \\
\hline 3 & Jumlah siswa yang mendapat nilai diatas KKM (70) & 21 \\
\hline 4 & Presentase siswa yang mendapat nilai diatas KKM (70) & $65,6 \%$ \\
\hline 5 & Jumlah siswa yang mendapat nilai dibawah KKM (70 & 11 \\
\hline 6 & Presentase siswa yang mendapat nilai dibawah KKM (70) & $34,4 \%$ \\
\hline
\end{tabular}

Nilai rata-rata hasil post test, dapat dihitung dari :

$\dot{X}=\frac{\sum X}{\sum N}$, Jadi $\dot{X}=\frac{2335}{32}=73,0$ 
Nilai KKM $=70$. Jadi sudah ada peningkatan prestasi belajar, namun hanya sedikit. Rumus Ketuntasan Individu (prestasi belajar siswa) $=$ $\frac{\sum \text { siswa yang mendapat nillai } \geq 70}{\sum \text { siswa }} \times 100 \%$

Jadi, Ketuntasan Individu (prestasi belajar siswa) $=\frac{21}{32} \times 100 \%=65,6 \%$

Masing kurang dari indicator pencapaian siklus I sebesar 85\% atau lebih. Maka dilanjutkan diskusi pembelajaran dengan Metode Problems Based Learning pada siklus II.

Tabel berikut adalah daftar frekuensi nilai post test siklus I Matematika Barisan dan Deret Bilangan dengan soal pengerjaan siswa kelas IX E SMP Negeri 1 Kalidawir Tulungagung setelah pembelajaran menggunakan Metode Problems Based Learning, dengan nilai minimal KKM sebesar 70:

Tabel 3 Daftar Nilai Ulangan Harian Siklus I

\begin{tabular}{|l|l|l|}
\hline Nilai & Frekuensi & Prosentase \\
\hline $0-40$ & 0 & $0,0 \%$ \\
\hline $41-69$ & 11 & $34,4 \%$ \\
\hline $70-100$ & 21 & $65,6 \%$ \\
\hline Jumlah & 32 & $100 \%$ \\
\hline
\end{tabular}

Dari tabel diatas dapat kita lihat terdapat 11 siswa atau $34,4 \%$ yang mendapat nilai antara 41 - 69, dan 21 siswa atau 65,6\% yang mendapat nilai antara 70 - 100. Dengan ketentuan nilai KKM 70, dapat disimpulkan jika pencapaian prestasi nilai $70-100$, maka prestasi belajar siswa telah meningkat dari $40,6 \%$ menjadi $65,6 \%$. Namun karena belum mencapai target indicator pencapaian siklus I sebesar $85 \%$ atau lebih, maka akan dilanjutkan ke Siklus II.

Selain itu, dari proses wawancara diperoleh kesimpulan bahwa beberapa siswa menjadi bersemangat dalam belajar Matematika, karena pelaksanaan kegiatan belajar Matematika dengan Metode Problems Based Learning ini dilaksanakan dengan langsung secara mandiri oleh siswa, dan melaksanakan kegiatan bersama kelompok sehingga lebih ringan. Meskipun masih terdapat kendala-kendala seperti yang telah diuraikan dalam laporan observasi.

\section{Siklus II}

Dalam pelaksanaan proses pembelajaran, Guru telah melaksanakan perbaikan dari siklus I, siswa sudah mengalami kemajuan dan pelaksanaan-pun telah berjalan baik. Namun Guru menemukan masalah baru dalam pelaksanaan siklus II, yaitu: 1) Beberapa siswa tampak sedikit kebingungan mencari permasalahan yang dapat dijadikan persoalan Barisan dan Deret Bilangan. Namun diantisipasi oleh peneliti dengan memberikan pengarahan secara langsung kepada siswa. 2) Masih terdapat 3-4 siswa yang malu dalam presentasi dan kurang aktif dalam diskusi kelompok.

Adapun prosentase hasil observasi dalam pelaksanaan diskusi pada siklus II dapat dilihat dari tabel bawah ini. Perhitungan prosentase keberhasilan siklus II di bawah ini diskusikan juga dengan teman sejawat. 
Tabel 4 Prosentase Hasil Observasi Siklus II

\begin{tabular}{|l|l|l|}
\hline No & Kegiatan Siswa & Prosentase \\
\hline 1 & Kelengkapan menyiapkan alat dan bahan diskusi & $80 \%$ \\
\hline 2 & Keruntutan langkah-langkah dalam pelaksanaan kegiatan diskusi & $85 \%$ \\
\hline 3 & Keaktifan siswa selama melaksanakan kegiatan diskusi & $90 \%$ \\
\hline 4 & Keaktifan siswa dalam mengutarakan pendapat saat berdiskusi & $88 \%$ \\
\hline 5 & Kesimpulan akhir sesuai diskusi & $85,8 \%$ \\
\hline
\end{tabular}

Hasil post test pada siklus kedua dapat menjadi perhitungan persentase peningkatan prestasi belajar siswa. Dengan acuan penilaian tetap berdasarkan nilai KKM yang telah ditetapkan yaitu paling sedikit siswa memperoleh nilai 70 . Adapun rekapitulasi hasil test siklus II adalah sebagai berikut:

Tabel 5 Hasil Post Test Siklus Kedua

\begin{tabular}{|l|l|l|}
\hline No & Deskripsi & Nilai \\
\hline 1 & Jumlah Nilai & 2690 \\
\hline 2 & Rata-rata Hasil Post Test & 84,1 \\
\hline 3 & Jumlah siswa yang mendapat nilai diatas KKM (70) & 28 \\
\hline 4 & Presentase siswa yang mendapat nilai diatas KKM (70) & $87,5 \%$ \\
\hline 5 & Jumlah siswa yang mendapat nilai dibawah KKM (70 & 4 \\
\hline 6 & Presentase siswa yang mendapat nilai dibawah KKM (70) & $12,5 \%$ \\
\hline
\end{tabular}

Nilai rata-rata hasil post test, dapat dihitung dari :

$\dot{X}=\frac{\sum X}{\sum N}$, Jadi $\dot{X}=\frac{2690}{32}=84,1$

Nilai $\mathrm{KKM}=70$. Jadi sudah ada peningkatan prestasi belajar yang signifikan.

Rumus Ketuntasan Individu (prestasi belajar siswa) = $\frac{\sum \text { siswa yang mendapat nilai } \geq 70}{\sum \text { siswa }} \times 100 \%$

Jadi, Ketuntasan Individu (prestasi belajar siswa) $=\frac{28}{32} \times 100 \%=87,5 \%$

Telah mencapai indicator pencapaian siklus II sebesar $85 \%$ atau lebih. Maka tidak perlu dilanjutkan diskusi pembelajaran dengan Metode Problems Based Learning pada siklus III.

Tabel berikut adalah daftar frekuensi nilai post test siklus II Matematika dengan Barisan dan Deret Bilangan siswa kelas IX E SMP Negeri 1 Kalidawir Tulungagung setelah pembelajaran menggunakan Metode Problems Based Learning siklus II, dengan nilai minimal KKM sebesar 70:

Tabel 6 Daftar Nilai Ulangan Harian Siklus II

\begin{tabular}{|l|l|l|}
\hline Nilai & Frekuensi & Prosentase \\
\hline $0-40$ & 0 & $0,0 \%$ \\
\hline $41-69$ & 4 & $12,5 \%$ \\
\hline $70-100$ & 28 & $87,5 \%$ \\
\hline Jumlah & 32 & $100 \%$ \\
\hline
\end{tabular}

Dari tabel diatas dapat kita lihat terdapat 4 siswa atau $12,5 \%$ yang mendapat nilai antara $41-69$, dan 28 siswa atau 87,5\% yang mendapat nilai antara 70 - 100. Dengan ketentuan nilai KKM 70, dapat disimpulkan jika 
pencapaian prestasi nilai 70 - 100, maka prestasi belajar siswa telah meningkat dari $65,6 \%$ menjadi $87,5 \%$. Dengan $87,5 \%$ maka telah tercapai indicator pencapaian siklus II sebesar yang $85 \%$ atau lebih, maka tidak perlu dilanjutkan ke Siklus III.

Selain itu, dari proses wawancara diperoleh kesimpulan bahwa beberapa siswa menjadi bersemangat dalam belajar Matematika, karena pelaksanaan kegiatan belajar Matematika yang berMetode Problems Based Learning ini dilaksanakan dengan melibatkan permasalahan yang ada di lingkungan sekitar, serta melaksanakan kegiatan bersama kelompok menjadikan mereka lebih rileks dan ringan dalam mengerjakan laporan kegiatan. Meskipun masih terdapat kendala-kendala seperti yang telah diuraikan dalam laporan observasi.

\section{PEMBAHASAN}

Berdasarkan hasil pelaksanaan pada siklus I, II dapat dinyatakan bahwa terjadi peningkatan kualitas pembelajaran yang tampak dan perolehan hasil evaluasi dan keaktifan siswa. Dari tabel 4.2 dan gambar 4.2 siklus I hasil observasi menunjukkan, prosentase keberhasilan kelengkapan menyiapkan alat dan bahan diskusi $45 \%$, prosentase keruntutan langkah-langkah yang ditempuh dalam pelaksanaan diskusi $45 \%$, prosentase keaktifan siswa dalam melaksanakan kegiatan diskusi $60 \%$, prosentase keaktifan siswa dalam mengutarakan pendapat saat berdiskusi $50 \%$ dan prosentase hasil penarikan kesimpulan akhir sesuai diskusi $50 \%$.

Berdasarkan tabel 4.5 dan gambar 4.5 siklus II hasil observasi menunjukkan, prosentase keberhasilan metode kelengkapan menyiapkan alat dan bahan diskusi siswa yang disiapkan $80 \%$, prosentase keruntutan langkah-langkah yang ditempuh dalam pelaksanaan diskusi $85 \%$, prosentase keaktifan siswa dalam melaksanakan kegiatan diskusi $90 \%$, prosentase keaktifan siswa dalam mengutarakan pendapat saat berdiskusi $88 \%$ dan prosentase hasil penarikan kesimpulan akhir sesuai diskusi 85,8\%.

Dari daftar nilai (lihat lampiran) dapat kita lihat adanya prosentase kenaikan nilai Matematika mulai dari kondisi awal pra tindakan, diketahui baru 13 siswa atau $40,6 \%$ yang mengalami ketuntasan belajar dan mendapatkan nilai sesuai dengan KKM. Hasil evaluasi siklus I menunjukkan baru 21 siswa atau $65,6 \%$ yang mengalami ketuntasan belajar dan mendapat nilai sama dengan atau di atas KKM yaitu 70. Hal itu menunjukkan bahwa pelaksanaan siklus I belum mencapai keberhasilan, karena indicator pencapaian adalah sebesar $85 \%$ atau lebih. Siklus II menunjukkan ada 28 siswa atau 87,5\% dari 32 siswa yang mengalami ketuntasan belajar. Sehingga peneliti menyimpulkan bahwa pada siklus II ini peneliti telah mencapai keberhasilan dari penelitian tindakan kelas yang telah dilakukan.

Ketika peneliti melaksanakan siklus I, peneliti mengalami berbagai kendala antara lain masih ada siswa yang kesulitan membuat diskusi deret dan barisan Barisan dan Deret Bilangan. Masih ada kelompok yang bingung dalam mengikuti langkah-langkah yang tertera dalam lembar kegiatan. Masih ada beberapa siswa yang belum aktif dalam pelaksanaan diskusi. Ketika pelaksanaan diskusi, ada beberapa siswa yang tidak aktif menyampaikan pendapatnya. Dalam menyimpulkan hasil diskusi, terdapat 2 (dua) kelompok yang malu untuk presentasi, dan hanya terdapat 3 (tiga) siswa yang mengajukan pertanyaan. 
Peneliti kemudian melaksanakan siklus II sebagai perbaikan siklus I, sebelum pelaksanaan siklus II ini peneliti mengganti rencana pembelajaran Metode Problems Based Learning baru yaitu dengan memberikan tugas kepada siswa untuk membuat persoalan Barisan dan Deret Bilangan berdasarkan permasalahan yang ada di lingkungan sekitar. Dalam pelaksanaan diskusi, peneliti senantiasa memberi bimbingan untuk siswanya dalam melaksanakan langkahlangkah sesuai lembar kegiatan. Peneliti pun memberi bimbingan siswa saat berdiskusi untuk menarik kesimpulan. Dengan adanya motivasi guru berupa reward, siswa telah terlihat aktif dalam kegiatan pembelajaran dalam melaksanakan diskusi, presentasi di depan kelas dan berdiskusi menarik kesimpulan. Meskipun ada kendala beberapa siswa tampak sedikit kebingungan mencari permasalahan yang dapat dijadikan persoalan Barisan dan Deret Bilangan, namun dengan hasil prestasi belajar yang dicapai dapat disimpulkan bahwa penelitian tindakan kelas dari siklus II ini telah berhasil.

\section{KESIMPULAN}

Berdasarkan hasil penelitian tindakan kelas yang telah dilaksanakan dalam 2 siklus dengan menerapkan Metode Problems Based Learning dalam pembelajaran Matematika pada siswa kelas IX E SMP Negeri 1 Kalidawir Tulungagung, dapat dibuat kesimpulan sebagai berikut: Penerapan Metode Problems Based Learning dapat meningkatkan hasil belajar Matematika siswa kelas IX E SMP Negeri 1 Kalidawir Tulungagung.

\section{SARAN}

Berdasarkan hasil penelitian, maka ada beberapa saran yang dapat dipergunakan sebagai bahan pertimbangan dan sebagai bahan uraian penutup penelitian tindakan kelas ini, antara lain: (1) Bagi Guru, Hendaknya mempersiapkan secara cermat perangkat pendukung pembelajaran dan fasilitas belajar yang diperlukan, karena sangat mempengaruhi efektivitas dan efisiensi pembelajaran yang pada akhirnya berpengaruh pada proses dan hasil belajar Matematika siswa. Guru juga harus memahami dan memvariasikan metode yang sesuai materi yang dapat digunakan dalam proses pembelajaran, sehingga siswa tidak merasa bosan. (2) Bagi Siswa, Hendaknya ikut berperan aktif dalam proses pembelajaran, dan meningkatkan usaha belajar sehingga dapat memperoleh prestasi yang diharapkan. (3) Bagi Sekolah, Hendaknya mengupayakan pengadaan berbagai media pembelajaran Matematika untuk kelas.

\section{DAFTAR RUJUKAN}

Hudoyo, H. 1988. Strategi Belajar Mengajar Matematika. Jakarta : Depdikbud. Sanjaya, Wina. 2006. Strategi Pembelajaran Berorientasi Standar Proses Pendidikan. Jakarta: Kencana.

Soenarjo. 2008. Matematika 5. Jakarta: Departemen Pendidikan Nasional.

Sudjana. 2005. Metode \& Teknik Pembelajaran Partis Matematikatif. Bandung: Falah Production.

Surjadi. 1989. Membuat Siswa Aktif. Bandung: Bandar Maju.

Tritanto, 2007. Model Pembelajaran Inovatif Berorientasi Konstruktif. Jakarta:

Prestasi Pustaka. 